\title{
房総半島南部の下部鮮新統清澄層を切る脆性小断層群
}

\section{Outcrop-scale brittle faults in the Lower Pliocene Kiyosumi Formation, southern Boso Peninsula, central Japan}

\author{
佐藤活志 ${ }^{*}$ 山路 敦* 徳橋秀一** \\ Katsushi Sato*, Atsushi Yamaji* and Shuichi Tokuhashi**
}

\section{4 年 4 月 15 日受付. 2014 年 7 月 7 日受理.}

\section{京都大学大学院理学研究科地球惑星科学専攻}

Division of Earth and Planetary Sciences, Graduate School of Science, Kyoto University, Kyoto 606-8502, Japan

** 産業技術総合研究所地圈資源環境研究部門

Institute for Geo-Resources and Environment, AIST, Tsukuba 3058567, Japan

Corresponding author: K. Sato, k_sato@kueps.kyoto-u.ac.jp

房総半島南部に分布する下部鮮新統清澄層は, 砂岩を主体とする 砂岩泥岩凝灰岩互層からなる前弧海盆堆積体であり, 地質図規模の 褶曲をなしている (Fig. 1a). 清澄向斜南翼部の Fig. 1b の地点では, 変位量が数 $m$ 程度の小断層が多数見られ，ほぼ直立した東西の露頭 のあいだで地層と断層を対比できる (Figs. 2, 3). 断層の方向は多様 で，正・逆・横ずれ断層および層面滑り断層を含み(Fig. 4a), 破砕 帯は薄く癒着している(Fig. 4b)．断層による変形の結果として，同 じ地層が繰り返しており, 見かけの層厚が増している. 断層間の切 断関係と地層のずれから，断層の活動の順序が推定できる (Fig. 5). また, 露頭写真を用いて 2 次元歪を見積もると, 褶曲軸と直交方向 には $30 〜 40 \%$ 短縮したことがわかつた.このことは, 陸上に露出 した若い前弧海盆堆積体でも, 局所的には大変形を起こしているこ とを示す.

\section{文 献}

徳橋秀一 - 石原与四郎 (Tokushashi, S. and Ishihara, Y.), 2008, 千葉県清 和県民の森周辺の地質図 (Geological Map in and around the Forest

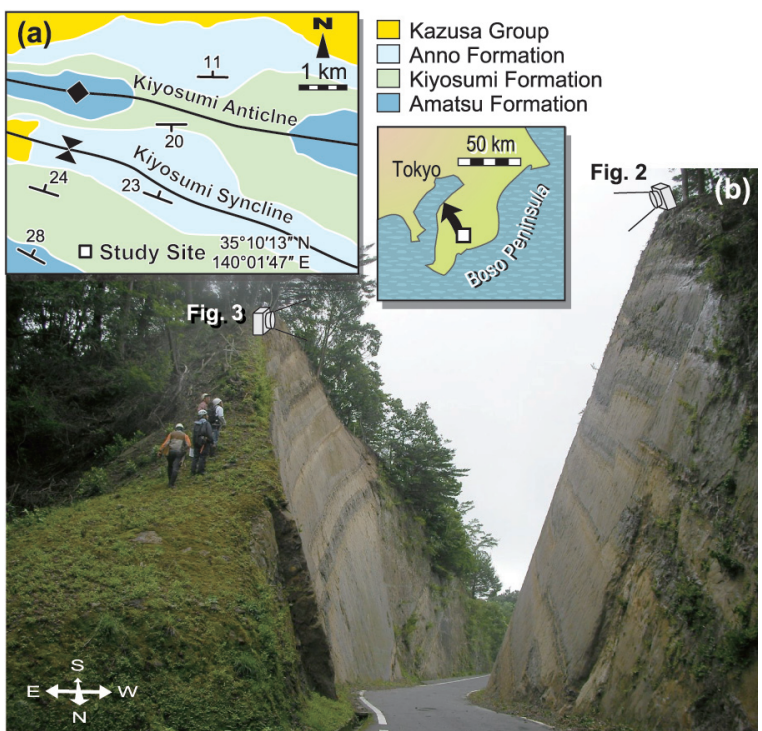

Fig. 1. (a) Geological map around the study site, simplified from Tokuhashi and Ishihara (2008). (b) Photograph of eastern and western road cuttings in which meso-scale faults and duplications of beds were observed in the Pliocene Kiyosumi Formation (inset: location map).

Park, "Seiwa-Kenmin-no-Mori" in Chiba Prefecture, Bōsō Peninsula, central Japan 1: 15,000), 産総研地質調査総合センター（Geol. Surv. Japan, AIST), 95p.

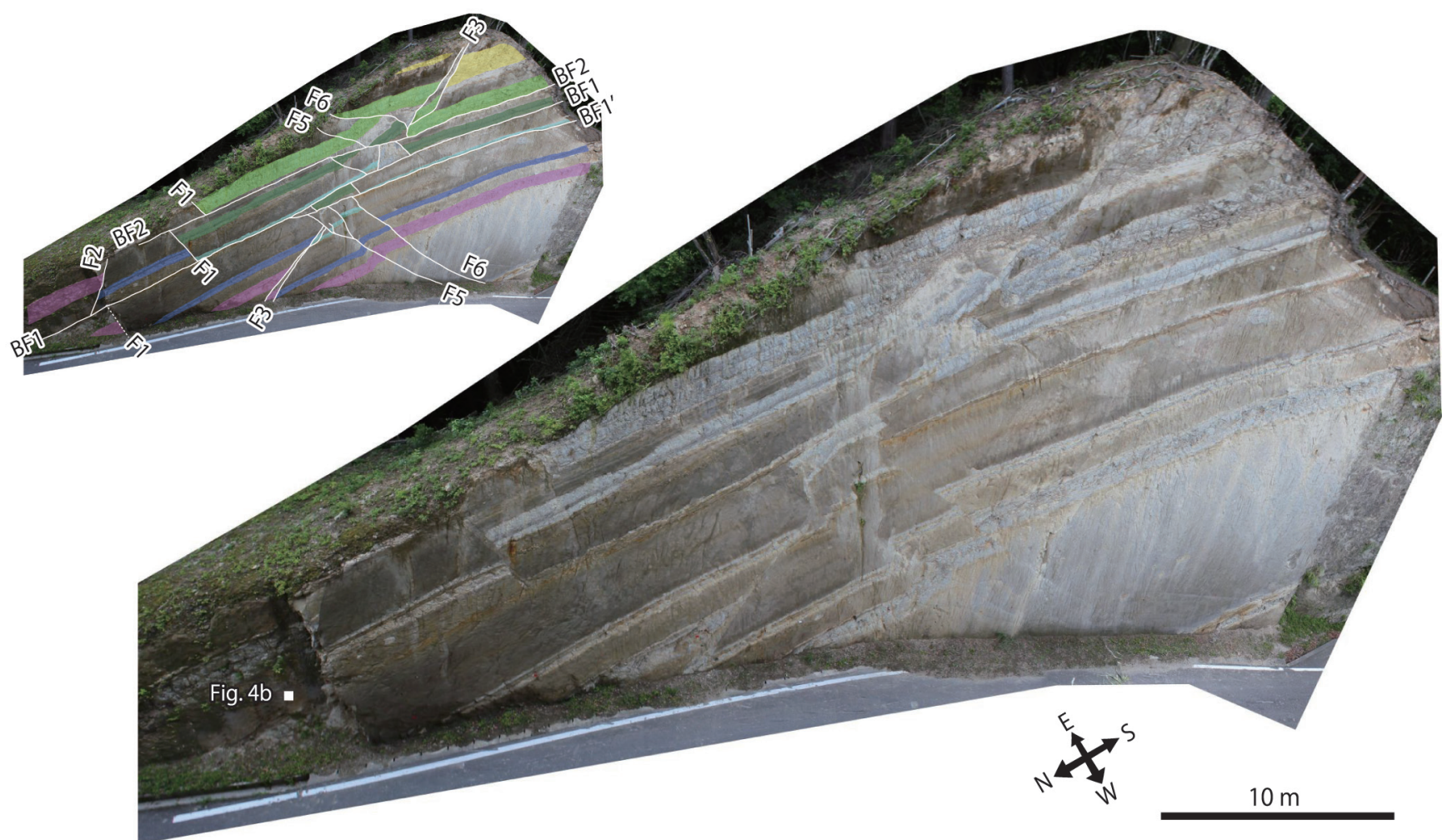

Fig. 2. Photograph showing the eastern road cutting (left hand side of Fig. 1b). In the inset, faults and marker silty beds are colored. BF1 and BF2 are bedding-parallel faults with southward vergence, opposite to the dip direction of the strata. 


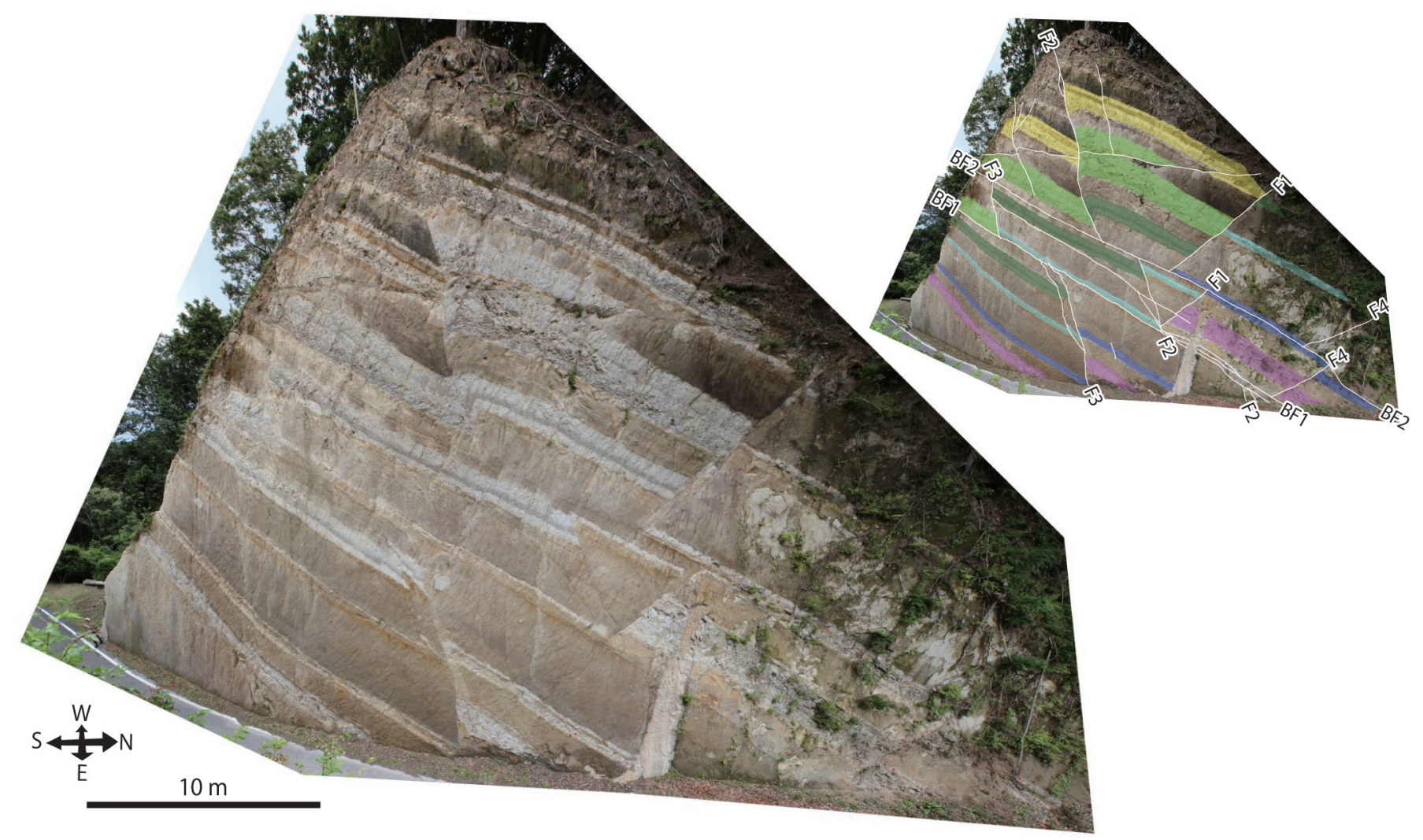

Fig. 3. Photograph showing the western road cutting (right hand side of Fig. 1b). The faults and the marker beds can be correlated with those on the eastern cutting (Fig. 2).
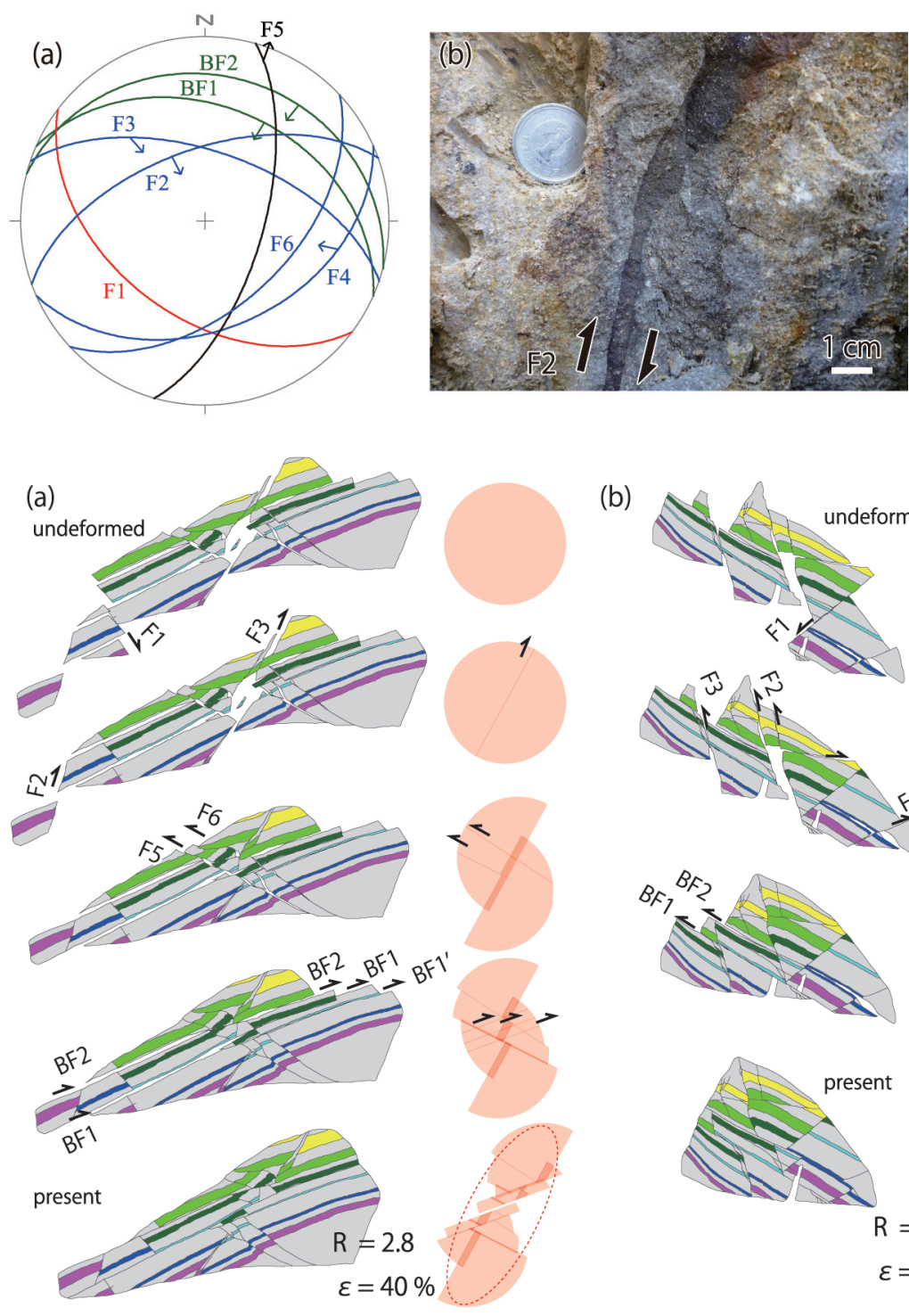

Fig. 4. (a) Stereogram showing the orientations of faults with lowerhemisphere and equal-area projection. Red, blue, black, and green girdles show the normal, reverse, strike-slip, and bedding-parallel faults, respectively, shown in Figs 2 and 3. Arrows on the girdles show the slip directions of hanging walls. (b) Photograph showing the thin and cohesive gouge of fault F2, the location of which is shown in Fig. 2. (b)
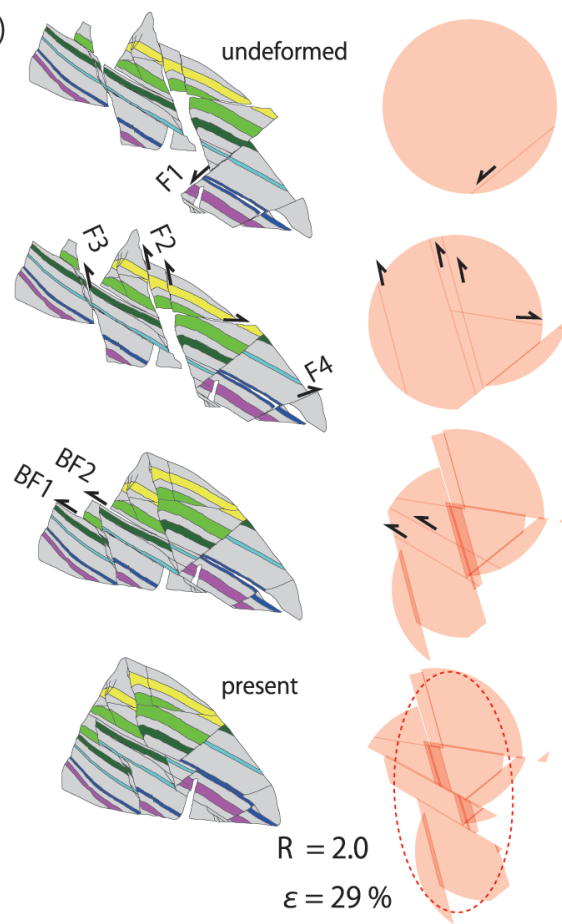

Fig. 5. Deformations along the eastern (a) and western (b) road cuttings (Figs 2 and 3 ). The original states (top) were restored by using the colored silty horizons as displacement markers. The pink circles trace the displacement history, starting with circles at the top (undeformed) and the final states at the bottom. Red dotted ellipses are the strain ellipses which roughly outline the final shapes. The contractional strain $\varepsilon$ on the minor axis of strain ellipse is calculated from the aspect ratio $R$ by solving $R=1 /(1+\varepsilon)^{2}$, where isochoric deformations are assumed. 